\title{
Basic and clinical immunology - 3023. Influence of fexofenadine hydrochloride on uteroglobin production from nasal epithelial cells in vitro and in vivo
}

\author{
Kenichi Kanai ${ }^{1 *}$, Kazuhito Asano ${ }^{2}$, Atsuko Furuta', Takeyuki Sanbe ${ }^{1}$, Harumi Suzaki ${ }^{1}$
}

From 2nd WAO International Scientific Conference (WISC 2012)

Hyderabad, India. 6-9 December 2012

\section{Background}

Uteroglobin (CC10) is well known to be an immuno-suppressive protein secreted from airway epithelial cells after inflammatory stimulation and function in development of allergic disorders. Although histamine $\mathrm{H}_{1}$ receptor antagonists are used for the treatment of allergic disorders, the influence of the agents on $\mathrm{CC} 10$ production is not well understood. In the present study, we examined the influence of a histamine $\mathrm{H}_{1}$ receptor antagonist, fexofenadine hydrochloride (FEX) on CC10 production in vitro and in vivo.

\section{Methods}

Nasal epithelial cells $\left(5 \times 10^{6}\right.$ cells $\left./ \mathrm{ml}\right)$ were stimulated with $20 \mathrm{ng} / \mathrm{ml} \mathrm{TNF}-\alpha$ in the presence of various concentrations of FEX for $24 \mathrm{~h}$. CC10 levels in culture supernatants were examined by ELISA. Patients with Japanese cedar pollinosis were orally treated with FEX twice a day at a single dose of $60 \mathrm{mg}$ for two weeks during Japanese cedar pollen season (February 2011 to April 2011). CC10 levels in nasal secretions were also examined by ELISA.

\section{Results}

The addition of FEX into epithelial cell cultures caused dose-dependent increase in the ability of cells to produce CC10 in response to TNF- $\alpha$ stimulation, and the minimum concentration that caused significant increase was $200 \mathrm{ng} / \mathrm{ml}$. Oral administration of FEX for two weeks also increased CC10 levels in nasal secretions from pollinosis patients along with attenuation of clinical symptoms.

${ }^{1}$ Otorhinolaryngology, Showa University, Tokyo, Japan

Full list of author information is available at the end of the article

\section{Conclusions}

The ability of FEX to enhance CC10 production may account, at least in part, for the clinical efficacy of the agent on allergic disorders, including allergic rhinitis

\section{Author details}

'Otorhinolaryngology, Showa University, Tokyo, Japan. ${ }^{2}$ Physiology, Showa University, Japan.

Published: 23 April 2013

doi:10.1186/1939-4551-6-S1-P199

Cite this article as: Kanai et al:: Basic and clinical immunology - 3023. Influence of fexofenadine hydrochloride on uteroglobin production from nasal epithelial cells in vitro and in vivo. World Allergy Organization Journal 2013 6(Suppl 1):P199.
Submit your next manuscript to BioMed Central and take full advantage of:

- Convenient online submission

- Thorough peer review

- No space constraints or color figure charges

- Immediate publication on acceptance

- Inclusion in PubMed, CAS, Scopus and Google Scholar

- Research which is freely available for redistribution
() Biomed Central 